\title{
Impacts of Handling and Transport on the Growth and Survival of Balled-and-burlapped Trees
}

\author{
Andrew K. Koeser and J. Ryan Stewart ${ }^{1}$ \\ Department of Natural Resources and Environmental Sciences, University of \\ Illinois at Urbana-Champaign, 1201 South Dorner Drive, Urbana, IL 61801
}

Germán A. Bollero and Donald G. Bullock

Department of Crop Sciences, University of Illinois at Urbana-Champaign, 1102 South Goodwin Avenue, Urbana, IL 61801

\section{Daniel K. Struve \\ Department of Horticulture and Crop Science, The Ohio State University, 2001 Fyffe Court, Columbus, OH 43210}

Additional index words. transplant shock, woody plant, desiccation, shock, vibration, water stress

\begin{abstract}
Transplanted trees are exposed to numerous stresses from the time of harvest until establishment in the landscape. Although an individual stress factor may be the sole cause of plant death or decline, it is more likely a combination of stress factors cause reduced growth or death after planting. In an effort to isolate the stresses associated with three critical stages in the transplanting process (i.e., initial harvest, handling, and transport), 5-cm-caliper, balled-and-burlapped Acer rubrum L. 'Red Sunset' (red maple) and Acer platanoides L. 'Pond' (Norway maple) trees at three sites (Urbana, IL; Union, IL; and Manitowoc, WI) were subjected to three treatments: root-pruned, handled, and transported. Effects of water stress, root severance, and root-ball disruption on twig elongation and tree survival were measured for each treatment and compared with unaltered control trees. Twig elongation was greater in unaltered control trees when compared with root-pruned trees. In addition, root-pruned trees exhibited greater twig elongation when compared with either handled or transported trees suggesting that although initial root severance did affect growth, it was not as detrimental as lifting and handling. In addition, twig elongation was not different between handled and transported trees. Water potential measurements ranged from -0.2 to $-2.0 \mathrm{MPa}$, suggesting water stress was not a critical factor during the time of transplanting. Similarly, root-ball soil moisture varied little between treatments over the course of transplanting. Results suggest rough handling before and after transport should be minimized in an effort to maximize growth and transplant success.
\end{abstract}

Transplanted trees are exposed to numerous stresses from the time they are harvested until their eventual establishment within the landscape (Davies et al., 1972; Kozlowski and Davis, 1975; McKay, 1996). The digging process often separates a balled-and-burlapped tree from the majority of its root system. After this initial stress, trees are typically brought to a loading site, placed on trucks or trailers, and shipped to their intended destinations. At each stage of the transplanting process, trees are exposed to mechanical shock and vibration that can further disrupt the root system and cause considerable dam-

\footnotetext{
Received for publication 10 July 2008. Accepted for publication 19 Oct. 2008.

This research was partially funded by the Tree Research \& Education Endowment Fund.

We thank Jeff Edgar, Chris Hackett, Greg Oltman, and Roger Purcell for their donations of plant materials, labor, and logistical expertise.

${ }^{1}$ To whom reprint requests should be addressed; e-mail rstewart@illinois.edu.
}

age to trunks and crowns. Water is typically not available during transport; tissue desiccation can greatly affect tree survival if tarps or other coverings are not used to limit evaporative and transpirational losses. In addition, transplanted trees may be subjected to rapidly changing temperatures and humidity levels as they are moved from sunny to shady sites, from low to high elevations, in and out of box trailers, and across plant hardiness zones, all of which may occur in the course of a few hours (Watson and Himelick, 1997).

Water stress (Gilbertson and Bradshaw, 1985), mechanical damage (Nowak et al., 2004), or extreme temperatures (McKay, 1996) alone may be sufficient to severely damage or kill a transplanted tree. When these stressors are combined, the prospect of survival in the landscape is greatly reduced (McKay, 1996). Individual stress factors affect the growth and survival of trees in different ways. Stresses such as tissue desiccation may have an additive effect, in which many minor water-limiting events may continuously weaken a tree (McKay, 1996). However, this additive property is not universal among stress factors. Prolonged periods of mild mechanical stress generally do not equal one lethal event. In the case of stress caused by rough handling, it appears a threshold must be crossed before damage occurs (McKay, 1996).

Transplant shock describes the period of reduced growth that follows the digging and planting of a tree. Many consider water stress to be the key factor contributing to transplant shock and planting failure (Davies et al., 1972; Kozlowski and Davis, 1975; McKay, 1996). Water stress during the transplanting process is often the result of digging practices that greatly reduce the root system of nursery trees (Gilman, 1988). The undersized root system is incapable of replenishing water lost through transpiration within the crown (Kozlowski and Davis, 1975). Transplanted trees remain in this state of diminished growth until regrowth of the root system is sufficient to balance transpiration loss (Beeson and Gilman, 1992).

Severe root loss significantly affects survival and establishment rates of transplanted trees (Gilman, 1988; Watson, 1985). Root growth after transplanting has been estimated at 30 to $68 \mathrm{~cm}$ per year (Watson and Himelick, $1982 b$ ). Because smaller trees typically retain a greater percentage of their original root system compared with larger trees, the time needed to regenerate the roots they have lost is substantially reduced. Research has shown when planted at the same time, it is possible for a $10-\mathrm{cm}$-caliper tree to outgrow a 25 $\mathrm{cm}$-caliper tree in height and stem diameter within a few years (Watson, 1985).

Although root severance may have a negative impact on survival and growth of transplanted trees, pruning of lateral roots to stimulate regrowth of fine absorptive roots is common in the nursery trade (Watson and Himelick, 2005). This root-pruning may be done several times before actual harvest with each new cut made further away from the trunk. When the tree is finally dug for transplanting, the root ball is made large enough to contain the subsequent fibrous regrowth.

Gaining a greater knowledge of the stress factors that influence transplant success is imperative if the process is to be improved. Reduced growth and survival associated with transplanting stress can be a significant financial loss to a consumer. Although costs associated with tree death are easily noted, effects of transplant shock and growth reduction are not as obvious. Unless overly mature, trees typically increase in their economic and environmental worth as they grow in size in an urban setting (Maco and McPherson, 2003). With this in mind, hindering tree growth slows the financial return associated with the initial investment of tree planting. This diminished return is quantified as a reduction in carbon sequestration rates, storm water retention, energy savings, and in potential gains in property value (Maco and McPherson, 2003). 
We hypothesized that stresses associated with handling and transporting nursery stock during transplanting could be directly linked to reduced tree growth and survival within the first year of establishment. We also postulated that identifying the specific stress factors responsible for transplant shock and when they occur is crucial if the process is to be improved. Our objective was to determine the short-term impact (i.e., within 1 year) of transplanting on health and establishment of woody plants in the landscape by examining impacts of desiccation and mechanical damage on survival and growth of balled-andburlapped trees at defined stages in the continuum from harvest to transplanting. This was our rationale to use two commonly used cultivars of Acer L. (maple). Our intent was not to look at potential treatment differences between the two maple species, but rather be able to generalize our results to transplanting events of several woody species. We then used this information to identify key stages in the transplanting process that diminish transplanted tree growth and survival.

\section{Materials and Methods}

Experimental design. Three wholesale nurseries located in Urbana, IL (lat. $40^{\circ} 6^{\prime} 38^{\prime \prime} \mathrm{N}$, long. $-88^{\circ} 12^{\prime} 26^{\prime \prime} \mathrm{W}$ ); Union, IL (lat. $42^{\circ} 13^{\prime} 59^{\prime \prime} \mathrm{N}$, long. $-88^{\circ} 32^{\prime} 32^{\prime \prime} \mathrm{W}$ ); and Manitowoc, WI (lat. $44^{\circ} 5^{\prime} 8^{\prime \prime} \mathrm{N}$, long. $-87^{\circ} 39^{\prime} 27^{\prime \prime} \mathrm{W}$ ) were selected as study sites. These nurseries spanned a latitudinal gradient of over $485 \mathrm{~km}$ and represented growing conditions in USDA hardiness zones $5 \mathrm{~b}$ (Urbana) and 5a (Union and Manitowoc).

Acer rubrum L. 'Red Sunset' $(\mathrm{n}=40)$ and Acer platanoides L. 'Pond' $(\mathrm{n}=60)$ were selected for this study. Twenty trees of each species were located at both the Urbana and Union sites. Acer rubrum was not present at the Manitowoc site. Tree caliper, which was measured $15 \mathrm{~cm}$ above the soil line, ranged from 4.5 to $5 \mathrm{~cm}$. Trees at each site were initially planted as bare-root liners. They received no fertilization or supplemental irrigation before treatment initiation. Plots were disked occasionally throughout the treatment period for weed control.

Before the experiment, all trees were randomly assigned one of four treatments: control, root-pruned, root-pruned + handled, and root-pruned + handled + transported, which will be referred to hereafter as control, root-pruned, handled, and transported, respectively. Each treatment was replicated five times per species per site. Individual trees served as experimental units. Control trees were not root-pruned or transplanted. Roots of trees assigned to the root-pruned treatment were severed with a hydraulic tree spade at $36 \mathrm{~cm}$ from the trunk to create a $72-\mathrm{cm}$-diameter root ball but were not lifted from the ground to minimize additional rootball disruption. After retracting the blades of the tree spade, efforts were taken to replace any disturbed soil and reduce air pockets that could potentially lead to root desiccation.
Trees in the handled and transported treatments were dug with a mechanical tree spade to create a $72-\mathrm{cm}$-diameter root ball; balled and burlapped; and moved to the loading area with a skid steer loader equipped with pallet forks. Trees were then loaded onto the trucks with the loaders. These loaders were also used to place the handled and transported trees next to their original holes for planting. Trees in the handled treatment, however, were not transported. These trees remained at the loading area while the transported trees were in transit. No supplemental watering was provided because it was not available to the trees in transport.

Trees assigned to the transported treatment were transported $450 \mathrm{~km}$ (Urbana, $\approx 7 \mathrm{~h}$ ), $150 \mathrm{~km}$ (Union, $\approx 8 \mathrm{~h}$ ), or $580 \mathrm{~km}$ (Manitowoc, $\approx 8 \mathrm{~h}$ ). Trees were securely fastened to a flatbed trailer to prevent excess movement and covered with an air-permeable tarp for protection. All transported trees were delivered back to their nursery of origin. On return, both the transported and handled trees were returned to their original planting holes within each study site.

Planting and handling followed ANSI A300 standards (Johnson, 2005). All planting holes were dug by a mechanical tree spade during the initial harvest. These holes were widened two to three times beyond their original diameter with hand shovels to reduce glazing, compaction, and to facilitate root growth and wire basket removal.

Industry-standard wire baskets were used to stabilize root balls of the handled and transported trees during the transplanting process. Before placing a tree in the planting hole, the bottom third of the basket was removed. Once the tree was settled and the base of the root ball had been supported with backfilled soil, the remaining wire was removed. In addition, twine was removed from the trunk and the burlap covering was pulled back to the sides of the root ball. Irrigation could not be provided at the sites and was not included as part of the tree establishment process.

Measurements. In an effort to gauge the extent and impact of tissue desiccation and root-ball damage on first-year twig elongation of transplanted nursery stock, plant water status, mechanical shock, and elongation were measured. Water stress for each tree was measured through of series of predawn water potential measurements using twig samples and a plant water status console (Soilmoisture Products, 3005 Series, Santa Barbara, CA). Three twigs from the outer canopy were measured per tree. Measurements were taken at three distinct points during the initial transplanting phase of the experiment: preharvest, postharvest, and postplanting. Preharvest measurements were made on 28 Mar. (Urbana), 18 Apr. (Union), and 25 Apr. 2007 (Manitowoc). Postharvest measurements were taken on 29 Mar. (Urbana), 20 Apr. (Union), and 26 Apr. 2007 (Manitowoc). Postplanting measurements were taken on 31 Mar., 21 Apr., and 28 Apr. 2007 at the Urbana, Union, and Manitowoc sites, respectively.
To determine soil water availability and root-ball desiccation, soil moisture at three points on the root-ball surface were taken $\approx 15 \mathrm{~cm}$ from the trunk with a ThetaProbe with 6-cm wave guides (model ML2x; DeltaT Devices, Cambridge, U.K.). Soil moisture measurements were taken for each tree in unison with the water potential measurements. Three subsamples were taken per tree in an effort to control experimental error.

To determine the magnitude of mechanical shock, 10- $g$ shock loggers (Lo-Gee; Brand Electronics, Whitefield, ME) were secured to the base of trunks of handled $(\mathrm{n}=3)$ and transported $(\mathrm{n}=2)$ trees. These loggers were set to record gravitational forces 100 times per second $(100 \mathrm{~Hz})$. Although this sampling allowed for measurement of both shock and vibration, total logging time was limited to $\approx 68 \mathrm{~min}$. In addition, difficulties with equipment at the two northern sites (Union and Manitowoc) prevented successful logging during handling and transport.

Air temperature and precipitation measurements at each nursery site were accessed through local weather stations to gauge spring and summer growing conditions. Additionally, temperature and relative humidity were continuously measured with a datalogger (HOBO Pro Series; Onset Computer Corp., Bourne, MA) as the transported trees were en route.

Soil types were noted at each location. At the Urbana site, the A. rubrum were planted in Flanagan Silt loam (fine, smectitic, mesic Aquic Argiudolls), whereas the A. platanoides were grown in Drummer silty clay loam (fine-silty, mixed, superactive, mesic Typic Endoaquolls) (Endress, 2001). The $A$. rubrum at the Union site were planted in $\mathrm{La}$ Rose loam (fine-loamy, mixed, mesic Typic Argiudolls), whereas the $A$. platanoides were cultivated in Parr Silt loam (fine-loamy, mixed, mesic Oxyaquic Hapludalf) (Calsyn, 2001). At the Manitowoc site, the A. platanoides were established in a Keowns very fine sandy loam (coarse-loamy, mixed, superactive, nonacid, mesic Mollic Endoaquepts) (U.S. Dept. Agr., 2007).

Three shoots with the greatest diameter were selected from the lowest three dominant branches and measured for twig elongation. Measurements for all trees were taken after fall leaf drop on 24 Nov. (Manitowoc), 25 Nov. (Union), and 19 Dec. 2007 (Urbana). Transplant shock-induced tree mortality was noted at the end of the growing season and used to calculate transplant success rate.

Data analysis. Root-ball soil moisture content, tree water potential, and twig elongation were all analyzed by analysis of variance (ANOVA) with the MIXED procedure of SAS/STAT (SAS v. 9.1; SAS Institute Inc., Cary, NC). The experiment was conducted as a split plot in a randomized complete block design. Locations were treated as blocks and considered random. At each location, tree species was the main plot and treatment (i.e., control, root-pruned, handled, and transported) was the split plot with multiple trees as subsamples. In addition, 
for the variables root-ball soil moisture and water potential, another model included day of measurement (i.e., before harvest, after harvest, and after planting) that was treated as another split plot in time. Differences in twig elongation among treatments were compared using Tukey's multiple comparison test with an experimentwise error rate of $\alpha=0.05$.

Only trees that survived the entire growing season were included in the twig elongation analysis. Tree survival percentage rates were calculated for each block $\times$ species $\times$ treatment combination.

Shock data were analyzed descriptively to determine measures of mean, median, SD, and variance. This analysis was completed using all peak acceleration measurements. In addition, all peak accelerations above a $1.5-\mathrm{g}$ threshold were analyzed separately in accordance with previous work involving bareroot conifer seedlings (Stjernberg, 1996).

\section{Results}

Water stress. Mean predawn water potential values during the $3-\mathrm{d}$ transplanting phase of the study ranged from $-0.96 \mathrm{MPa}$ for control trees after harvest to $-1.34 \mathrm{MPa}$ for root-pruned trees after planting. Both mean and median water potential for all trees were $-1.08\left( \pm 2.96 \times 10^{-2} \mathrm{SE}\right) \mathrm{MPa}$. Effects of treatment $(P=0.05)$ and measurement day $(P<0.0001)$ had impacts on water potential. However, water potential was unaffected by the main effect of species $(P=0.79)$. Significant interactions included measurement date $\times$ treatment $(P=0.06)$ and measurement date $\times$ species $(P<0.0001)$. The two-way interaction of species $\times$ treatment $(P=0.25)$ and the three-way interaction of measurement date $\times$ species $\times$ treatment $(P=0.99)$ were not considered significant.

Root-ball soil moisture. Root-ball soil moisture during the transplant process ranged from 0.10 to $0.45 \mathrm{~m}^{3} \mathrm{H}_{2} \mathrm{O} / \mathrm{m}^{3}$ soil. Mean and median root-ball moisture content was 0.29 $\left( \pm 2.20 \times 10^{-3} \mathrm{SE}\right) \mathrm{m}^{3} \mathrm{H}_{2} \mathrm{O} / \mathrm{m}^{3}$ soil. Root-ball moisture did not vary by tree species $(P=$ $0.88)$ or treatment $(P=0.91)$. However, the main effect of measurement date had an effect on root-ball moisture content $(P<$ $0.0001)$. Interaction terms of species $\times$ treatment $(P=0.87)$, species $\times$ day $(P=0.11)$, treatment $\times$ day $(P=0.68)$, and species $\times$ treatment $\times$ day $(P=0.87)$ were all considered insignificant.

Shock and vibration. When compared with handled trees, transported trees experienced $88 \%$ fewer shocks above $1.5 \mathrm{~g}$ (Table 1). Although all three handled trees recorded peak acceleration levels above $1.5 \mathrm{~g}$, only one transported tree experienced shocks over the 1.5-g threshold (Table 1). Mean maximum peak acceleration above $1.5 \mathrm{~g}$ for the three handled trees was 1.6 times the maximum value reported for the one transported tree (Table 1). In addition, mean value for peak accelerations above $1.5 \mathrm{~g}$ for handled trees was $10 \%$ greater than that of transported trees (Table 1).
Temperature extremes. Daily temperatures during transplanting ranged from a high of $22.8^{\circ} \mathrm{C}$ at Urbana, IL, to a low of $8.89^{\circ} \mathrm{C}$ at Union, IL (Table 1). Nighttime low temperatures ranged from $1.67{ }^{\circ} \mathrm{C}$ at Union, IL, to $10.0^{\circ} \mathrm{C}$ at Manitowoc, WI (Table 2).

Survival and twig elongation. Handled and transported $A$. rubrum at the Urbana site experienced $100 \%$ mortality. However, trees in all other treatments experienced $100 \%$ survival regardless of species or site.

Across both species, control tree stem elongation was greater than that of the rootpruned trees $(P<0.0001)$ (Table 3$)$. However, compared with root-pruned trees, handled trees had less twig elongation $(P=0.02)$ (Table 3). There was no difference in twig elongation between handled and transported trees $(P=0.96)$ (Table 3$)$. ANOVA revealed that treatment affected twig elongation $(P<$ $0.0001)$. Both the main effect of species $(P<$ $0.0001)$ and the species $\times$ treatment interaction $(P=0.001)$ were significant.

\section{Discussion}

Water stress. Water stress was not a factor during the initial 4-d transplanting period. Although treatment $(P=0.05)$, day $(P<$ $0.0001)$, and the treatment $\times$ day interaction $(P<0.0001)$ had an effect on tree water potential, water potential measurements did not indicate any of the trees sustained irre- versible damage resulting from water stress. Overall, water potential measurements ranged from $-0.2 \mathrm{MPa}$ to $-2.0 \mathrm{MPa}$. The latter measurement, which represents the extreme low end of the 300 measurements collected in our study, was still above the -3 $\mathrm{MPa}$ stress threshold for ornamental trees originating from temperate forest environments (Larcher, 1980). The mean and median water potential values, which are more indicative of the majority of measurements, were both $-1.08\left( \pm 2.96 \times 10^{-2} \mathrm{SE}\right)$ $\mathrm{MPa}$.

Favorable climatic conditions and the dormant state of the trees were likely key factors in reducing water stress. Spring weather in Illinois and Wisconsin is typically mild and wet. According to 30-year normalized weather data, mean temperature spanned from $6.2{ }^{\circ} \mathrm{C}$ in Manitowoc, WI, to $10.6{ }^{\circ} \mathrm{C}$ in Urbana, IL (Fig. 1A). Mean precipitation during April harvest time ranged from 72.4 $\mathrm{mm}$ in Manitowoc, WI, to $92.7 \mathrm{~mm}$ and 94.2 $\mathrm{mm}$ in Urbana and Union, IL, respectively (Fig. 1B).

In addition to favorable climatic conditions, harvest was undertaken before budbreak. This is a common practice with balled-andburlapped trees and is necessary when planting bare-root material. Dormant, deciduous trees lack an actively transpiring leaf surface (Harris and Bassuk, 1994; Kozlowski and Davis, 1975). When combined with the cool,

Table 1. Summary of mechanical shock recordings by treatment (i.e., handled and transported) for balledand-burlapped Acer spp. at Urbana, IL. ${ }^{\text {z }}$

\begin{tabular}{|c|c|c|c|c|}
\hline \multirow[b]{2}{*}{ Treatment } & \multirow[b]{2}{*}{ Shocks $^{\mathrm{y}}$} & \multicolumn{2}{|c|}{ Peak acceleration above $1.5 \mathrm{~g}$} & \multirow{2}{*}{$\frac{\text { Peak acceleration }}{\text { Avg. } \pm \mathrm{SE}^{v}(g)}$} \\
\hline & & $\operatorname{Avg.} \operatorname{Max} \pm \operatorname{SE}^{\mathrm{x}}(g)$ & Avg. $\pm \mathrm{SE}^{\mathrm{W}}(g)$ & \\
\hline Handled & 153 & $3.61 \pm 0.85$ & $1.85 \pm 2.30 \times 10^{-2}$ & $0.50 \pm 5.23 \times 10^{-4}$ \\
\hline Transported & 19 & $2.28^{\mathrm{u}}$ & $1.65 \pm 3.14 \times 10^{-2}$ & $0.48 \pm 3.14 \times 10^{-4}$ \\
\hline
\end{tabular}

${ }^{\mathrm{z}}$ Measurements were taken as trees were moved from their origin in the nursery to the loading area (handled, $n=3$ ) and while en route to Hinsdale, IL (transported, $n=2$ ) on 29 Mar. 2007. Shock was recorded at $100 \mathrm{~Hz}$ for $68 \mathrm{~min}$

${ }^{\mathrm{y}}$ Shock events over $1.5 \mathrm{~g}$ for a minimum of $10 \mathrm{~ms}$.

${ }^{\mathrm{x}}$ Mean of maximum peak acceleration values above $1.5 \mathrm{~g}$ for handled and transported trees.

wMean of all peak acceleration values above $1.5 \mathrm{~g}$ for handled and transported trees.

${ }^{\mathrm{v}}$ Mean of all peak acceleration values.

"Only one experimental unit experienced peak accelerations above $1.5 \mathrm{~g}$ in the transported treatment making calculation of SE impossible.

Table 2. Daily maximum temperatures, minimum temperatures, and precipitation during transplanting of Acer rubrum $(\mathrm{n}=40)$ and Acer platanoides $(\mathrm{n}=60)$ at Urbana, IL, Union, IL, and Manitowoc, WI. $\mathrm{z}, \mathrm{y}$

\begin{tabular}{lcccc}
\hline & & \multicolumn{2}{c}{ Temperature $\left({ }^{\circ} \mathrm{C}\right)$} & Precipitation \\
Location & Day & Daily maximum & Daily minimum & 0.00 \\
\hline Manitowoc, WI & 25 Apr. 2007 & 13.3 & 6.67 & 4.57 \\
& 26 Apr. 2007 & 11.7 & 4.45 & 0.00 \\
& 27 Apr. 2007 & 13.9 & 6.11 & 0.00 \\
Union, IL & 28 Apr. 2007 & 22.2 & 10.0 & 0.00 \\
& 18 Apr. 2007 & 18.9 & 3.33 & 0.00 \\
& 19 Apr. 2007 & 8.89 & 5.00 & 0.00 \\
20 Apr. 2007 & 16.7 & 1.67 & 0.00 \\
& 21 Apr. 2007 & 21.7 & 5.00 & Trace \\
& 28 Mar. 2007 & 21.7 & 9.44 & 2.79 \\
& 29 Mar. 2007 & 23.3 & 8.89 & 0.00 \\
\hline
\end{tabular}

${ }^{\mathrm{z}}$ The first, second, and third dates at each location represent preharvest, harvest, and posttransplanting periods, respectively.

${ }^{y}$ Source: National Oceanic and Atmospheric Administration National Climatic Data Center. 


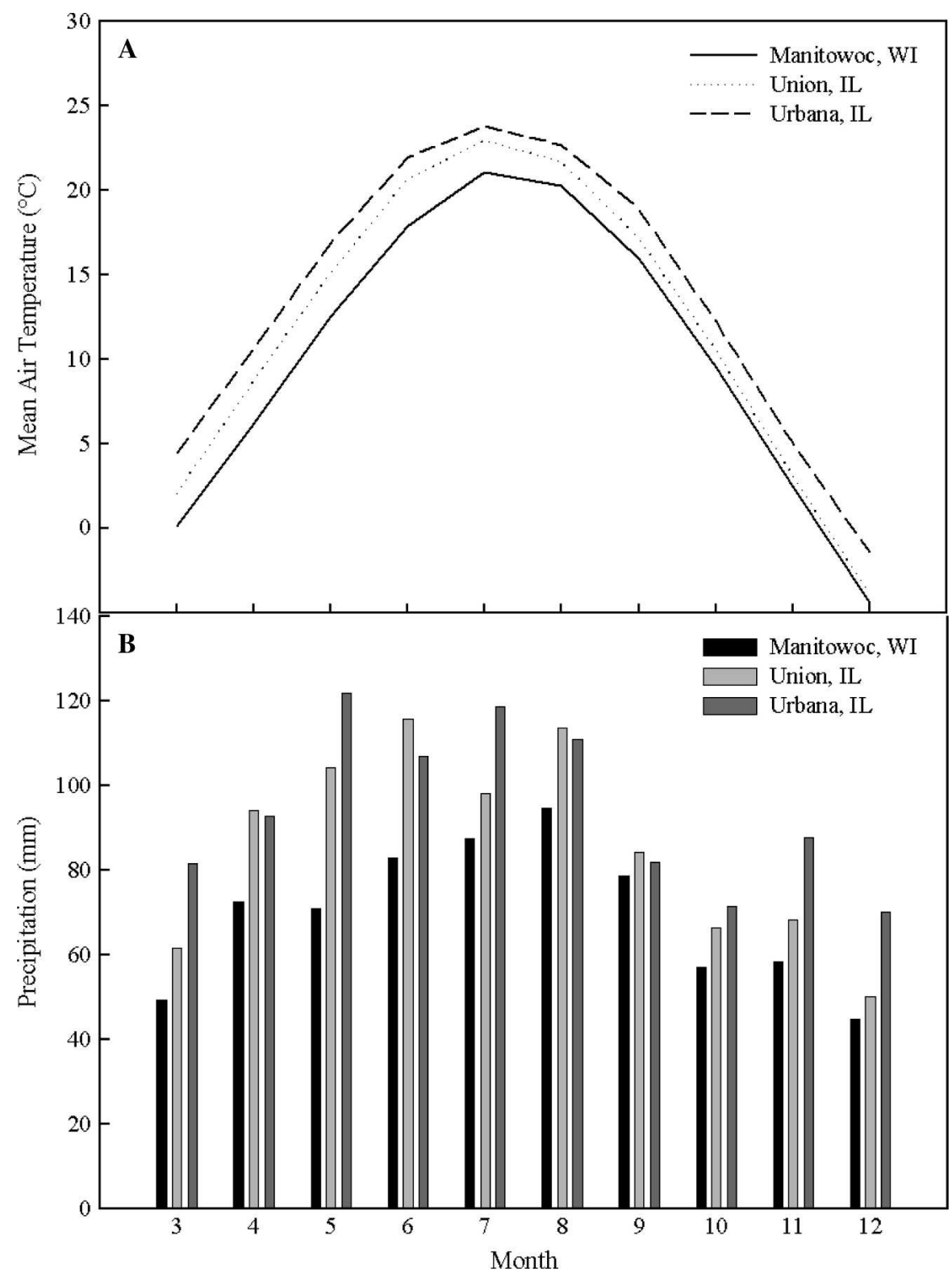

Fig. 1. Thirty-year normalized mean air temperature (A) and precipitation (B) data for Urbana, IL; Union, IL; and Manitowoc, WI.

rainy days of spring, water stress is generally minimized.

Irrigation was not provided after transplanting because it was not readily available at all three sites. Although water stress may not have been a factor at the time of transplanting, it likely had a part in the $100 \%$ mortality rates seen in the handled and transported A. rubrum trees at the Urbana, IL, site. As summer temperatures increased and soil water became limiting, it appears the diminished root systems of these trees could not replace water lost through transpiration.

Root-ball soil moisture. Unlike tissue water potential, root-ball moisture content did not vary by treatment (data not shown). However, as indicated by our water potential measurements, soil moisture appeared to be sufficient to replenish any water lost by the nursery tree during transplanting. Root-ball moisture content for the handled and trans- ported trees did not vary from those that remained in the soil, even when left out for $2 \mathrm{~d}$ at the loading site or on a trailer. Although soil moisture was not a limiting factor during this period, the trees were out of the ground for a short period of time. This may not be true for all transplanting events. Soil moisture levels should be monitored to prevent root desiccation while trees are being stored on site and after planting.

Shock and vibration. Harvested root balls can be extremely heavy and are relatively fragile. Although they were tightly laced and was incurred while handling the trees used for this study (A.K. Koeser, personal observation). Based on the shock logger data, it appears the majority of this disruption occurred during the handling process (Table 1 ). This seems very reasonable because the skid steers used to move the trees from the supported with a wire basket, visible damage nursery to the loading area lacked a shockabsorbing suspension and the trails connecting the two areas were often deeply rutted and extremely bumpy (A.K. Koeser, personal observation).

Less shock and vibration was associated with transporting nursery trees compared with handled trees (Fig. 2). Many semitrailers are equipped with a suspension system that dampens the shock associated with bumps and potholes. Also, when trees are transported long distances, the main duration of the trip may occur on paved roads free of obstructions.

Past research has suggested the frequency of shocks does not determine root damage; rather, it is the intensity of such events that is detrimental to plant growth (McKay et al., 1993). As a result, it seems highly likely the short but jarring journey from the nursery to the loading area far outweighs the relatively minor disturbances experienced while transporting trees long distances on paved roads and highways.

Survival and twig elongation. Even without supplemental irrigation, survival rates after transplanting were high. This may be partially attributed to the early-spring planting time, which gave trees several weeks to establish before the onset of drier and hotter summer conditions. Also, the soil surrounding the trees in the nursery was periodically cultivated to reduce weed competition for soil moisture.

Among surviving trees, twig elongation differed (Table 3). Control trees were not exposed to stresses associated with transplanting and, therefore, experienced the greatest growth (Table 3). Root-pruned trees had lower twig elongation when compared with the trees in the control treatment but had greater elongation when compared with handled or transported trees (Table 3). This suggests although root-pruning is stressful to trees, the act of lifting and moving a root ball from the surrounding soil slows establishment. Although the root system of a harvested tree is greatly reduced, a portion of its fine and structural roots is retained (Watson and Himelick, 1982a). However, unintentional root-ball disruption and the loss of close root-to-soil contact associated with rough handling likely damage fine roots (Watson and Himelick, 1997), further diminishing the capability of a tree to uptake water.

Removing soil from a root system of a tree during bare-root plant material production can result in a substantial loss (i.e., up to $90 \%$ ) of fine absorbing roots (Hartmann et al., 2002; Kozlowski and Davis, 1975). It appears highly probable similar losses may be incurred through mishandling of balledand-burlapped trees.

Although handled and transported trees exhibited lower levels of twig elongation than control and root-pruned trees, mean twig elongation measurements for handled and transported trees were not statistically different from each other (Table 3 ). This suggests stresses associated with transporting trees are 
no worse than those experienced when moving trees from the nursery to loading sites and from unloading sites to the landscape. When addressing the other factors of this study, it appears rough handling is the most detrimental stressor during spring transplanting (Fig. 2).

Temperature extremes. Temperature extremes did not appear to be a factor in this study. None of the trees showed any indications of frost or heat damage during transplanting. Daily temperatures were mild, ranging from $8.99{ }^{\circ} \mathrm{C}$ at Union, IL, to 23.3 ${ }^{\circ} \mathrm{C}$ at the Manitowoc, WI, site (Table 2). Nighttime temperatures did not drop below freezing.

Experimental design considerations. The two species used in this study were selected for their availability at each of the nurseries and for their prominence in the urban landscape. Both $A$. rubrum and $A$. platanoides were readily available at all three sites and are popular as street trees within many municipalities (Dirr, 1998; R. Purcell, G. Oltman, and J. Edgar, personal communication). In addition, these two species exhibit indeterminant growth (Borchert, 1991; Kozlowski, 1964; Romberger, 1963), which allowed us to gauge the treatment effects after one growing season. Acer platanoides is considered by many to be hardier or even weedier than A. rubrum (Dirr, 1998). The ability of $A$. platanoides to adapt to harsh urban environments has likely attributed to its abundance in the landscape and accounts for it superior performance in this study (Table 3).

Implications. Although root-ball moisture content and plant water stress during transplanting were not major factors in this study, the importance of maintaining plant water status cannot be underestimated. Many studies have identified plant desiccation as the main cause of transplant shock and failure (Kozlowski and Davis, 1975; McKay, 1996). Of the stresses encountered during spring transplanting of large-caliper, balled-andburlapped $A$. rubrum and A. platanoides, mechanical disruption of the root ball during the handling process combined with the initial shock of root severance appears to be the most important factor in limiting tree growth and survival. Because balled-andburlapped trees can be extremely heavy, many nurseries and landscaping firms use mechanical devices such as skid steers or ball carts. Practitioners should use equipment that prevents unnecessary movement of the root ball, dampens shock, and supports the weight of the root ball over a large area in an effort to minimize unnecessary damage.

Tree handling should also be minimized when transplanting to reduce stress and establishment time. Careful planning is needed to prevent unnecessary movements of trees at both the nursery loading area and landscape site. If trees are placed in mulch or composted material for an extended period of time, extra care must be taken because burlap may quickly deteriorate in warm, moist substrate.

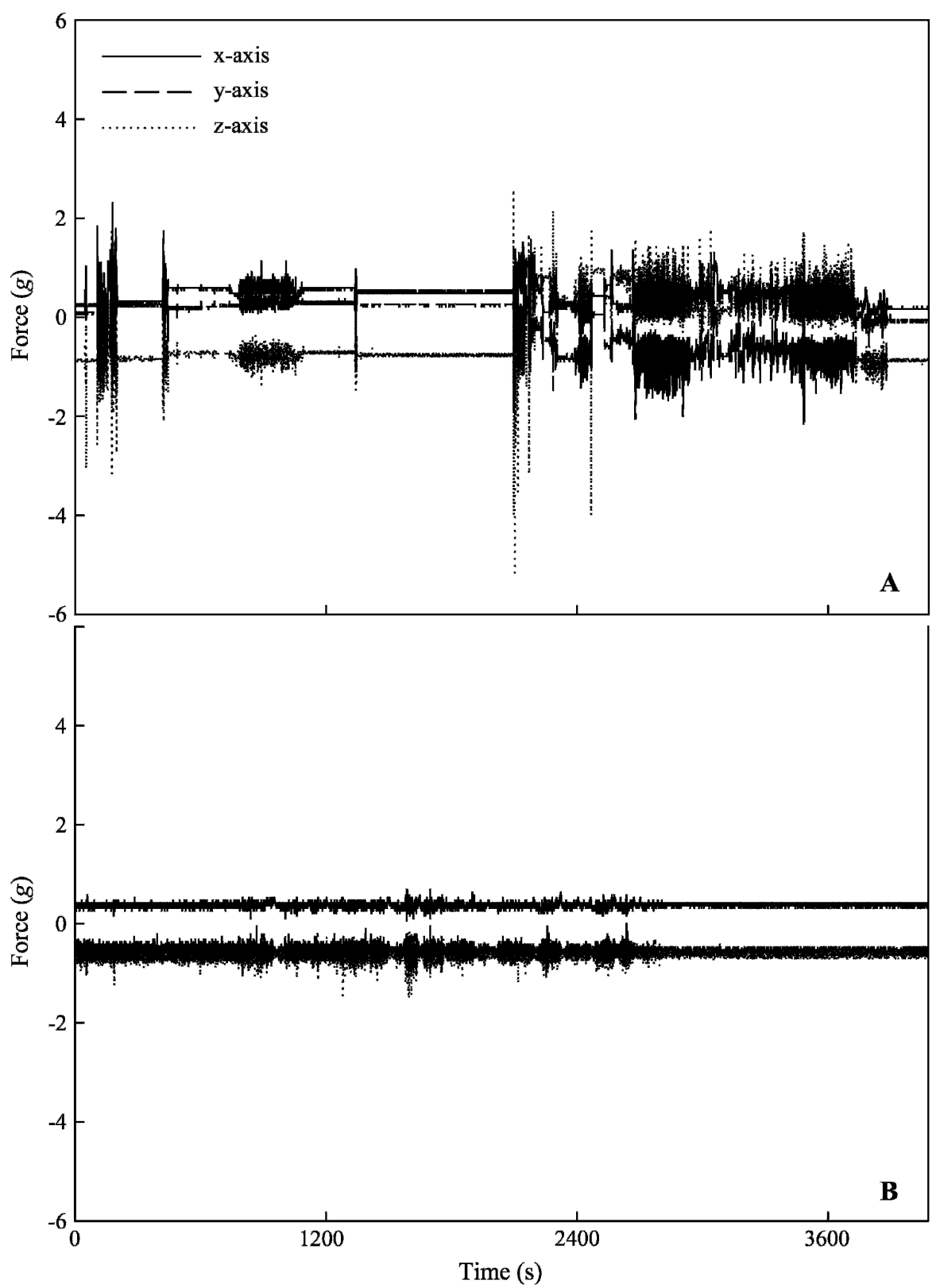

Fig. 2. Representative peak acceleration measurements of transported, balled-and-burlapped Acer spp. at Urbana, IL. (A) Shock and vibration associated with moving a balled-and-burlapped tree with a skid steer from origin in nursery to loading site for transport. (B) Shock and vibration associated with transporting balled-and-burlapped tree with a flatbed semi trailer on a paved highway. Measurements were taken in three axes at $100 \mathrm{~Hz}$ for $4080 \mathrm{~s}$ (68 min) on 29 Mar. 2007.

Table 3. Mean twig elongation for Acer rubrum (red maple) and Acer platanoides (Norway maple) grown at Urbana, IL (A. rubrum, $\mathrm{n}=20 ;$ A platanoides, $\mathrm{n}=20)$; Union, IL (A. rubrum, $\mathrm{n}=20 ;$ A . platanoides, $\mathrm{n}=20$ ); and Manitowoc, WI (A. platanoides, $\mathrm{n}=20)$ and combined species data. ${ }^{\mathrm{z}}$

\begin{tabular}{lccc}
\hline & \multicolumn{3}{c}{ Species } \\
\cline { 2 - 4 } Treatment & $\begin{array}{c}\text { A. platanoides } \\
\text { mean }(\mathrm{mm})\end{array}$ & $\begin{array}{c}\text { A. rubrum } \\
\text { mean }(\mathrm{mm})\end{array}$ & $\begin{array}{c}\text { Species combined } \\
\text { mean }(\mathrm{mm})\end{array}$ \\
\hline Control & $37.7^{\mathrm{y}}$ & 32.6 & $35.2 \mathrm{a}^{\mathrm{x}}$ \\
Root-pruned & 27.6 & 10.0 & $18.8 \mathrm{~b}$ \\
Handled & 16.2 & 5.8 & $11.0 \mathrm{c}$ \\
Transported & 15.8 & 6.5 & $11.2 \mathrm{c}$ \\
\hline
\end{tabular}

${ }^{2}$ Trees were assigned one of four treatments: control, root-pruned, handled, and transported.

y Data at the species level are provided for reference. The comparisons of interest are at the species combined level.

${ }^{x}$ Treatment means within the column followed by the same letter are not significant at the $\alpha=0.05$ level according to the Tukey's multiple comparison test.

Future studies should address what effect supplemental watering has on three of the treatments outlined in this study (i.e., root- pruned, handled, and transported). Numerous studies have demonstrated the value of irrigation after transplanting trees (Gilman et al., 
1998). Although there were noticeable differences in transplant growth and survival between treatments in this study, this difference may not be as distinct if soil moisture levels remain at optimal levels throughout the growing season.

\section{Literature Cited}

Beeson, R.C., Jr. and E.F. Gilman. 1992. Diurnal water stress during landscape establishment of slash pine differs among three production methods. J. Arboric. 18:281-286.

Borchert, R. 1991. Growth periodicity and dormancy, p. 221-245. In: Raghvendra, A.S. (ed.). Physiology of trees. Wiley, New York, NY.

Calsyn, D.E. 2001. Soil survey of McHenry County, Illinois - Part 1. Natural Resources Conservation Serv. U.S. Dept. Agr. 10 Apr. 2008. < http://soildatamart.nrcs.usda.gov/Manu scripts/IL111/0/McHenry_IL.pdf >.

Davies,W.J., T.T. Kozlowski, W.R. Chaney, and K. Lee. 1972. Physiological responses and growth of shade trees. Proc. of the Intl. Shade Tree Convention 22-29.

Dirr, M.A. 1998. Acer platanoides, p. 40-42. In: Manual of woody landscape plants. Stipes Publishing, Champaign, IL.

Endress, T.J. 2001. Soil survey of Champaign County, Illinois-Part 1. Natural Resources Conservation Serv. U.S. Dept. Agr. 10 Apr. 2008. <http://soildatamart.nrcs.usda.gov/Manu scripts/IL019/0/champaign_IL.pdf>.

Gilbertson, P. and A.D. Bradshaw. 1985. Tree survival in cities: The extent and nature of the problem. Arboric. J. 9:131-142.
Gilman, E.F. 1988. Predicting root spread from trunk diameter and branch spread. J. Arboric. 14:85-89.

Gilman, E.F., R.J. Black, and B. Dehgan. 1998. Irrigation volume and frequency and tree size affect establishment rate. J. Arboric. 24:1-9.

Harris, J.R. and N.L. Bassuk. 1994. Seasonal effects on transplantability of scarlet oak, green ash, Turkish hazelnut and tree lilac. J. Arboric. 20:310-316.

Hartmann, H.T., D.E. Kester, F.T. Davies, Jr., and R.L. Geneve. 2002. Techniques of propagation by cuttings, p. 341-410. In: Plant propagation principles and practices. 7th Ed. Prentice Hall, Englewood Cliffs, NJ.

Johnson, T. 2005. American national standard of tree care operations-Tree, shrub, and other woody plant maintenance-Standard practices (transplanting). Tree Care Ind. Assn., Manchester, $\mathrm{NH}$.

Kozlowski, T.T. 1964. Shoot growth in woody plants. Bot. Rev. 19:207-231.

Kozlowski, T.T. and W.J. Davis. 1975. Control of water balance in transplanted trees. J. Arboric. $1: 1-10$.

Larcher, W. 1980. Water relations, p. 206-267. In: Physiological plant ecology. 2nd Ed. SpringerVerlag, New York, NY.

Maco, S.E. and E.G. McPherson. 2003. A practica approach to assessing structure, function, and value of street tree populations in small communities. J. Arboric. 29:84-97.

McKay, H.M. 1996. A review of the effect of stresses between lifting and planting on nursery stock quality and performance. New For 13:363-393.
McKay, H.M., B.A. Gardiner, W.L. Mason, D.G. Nelson, and M.K. Hollingsworth. 1993. The gravitational forces generated by dropping plants and the response of Sitka spruce seedlings to dropping. Can. J. For. Res. 23:2443-2451.

Nowak, D.J., M. Kuroda, and D.E. Crane. 2004. Tree mortality rates and tree population projections in Baltimore, Maryland, USA. Urban Forestry Urban Greening 2:139 147.

Romberger, J.A. 1963. Meristems, growth and development in woody plants. U.S. Dept. Agr., Forest Service.

Stjernberg, E.I. 1996. Mechanical shock during transportation: Effects on seedling performance. New For. 13:395-414.

U.S. Dept. Agr. 2007. Web soil survey. Natural resources. Conservation Service. 3 June 2008. <http://websoilsurvey.nrcs.usda.gov/ app/>.

Watson, G.W. 1985. Tree size effects root regeneration and top growth after transplanting. J. Arboric. 11:37-40.

Watson, G.W. and E.B. Himelick. 1982a. Root distribution of nursery trees and its relationship to transplanting success. J. Arboric. 8:225229.

Watson, G.W. and E.B. Himelick. 1982b. Root regeneration of transplanted trees. J. Arboric. 8:305-310.

Watson, G.W. and E.B. Himelick. 1997. Principles and practice of planting trees and shrubs. Intl. Soc. Arboric., Champaign, IL.

Watson, G.W. and E.B. Himelick. 2005. Best management practices: Tree planting. Intl. Soc. Arboric., Champaign, IL. 